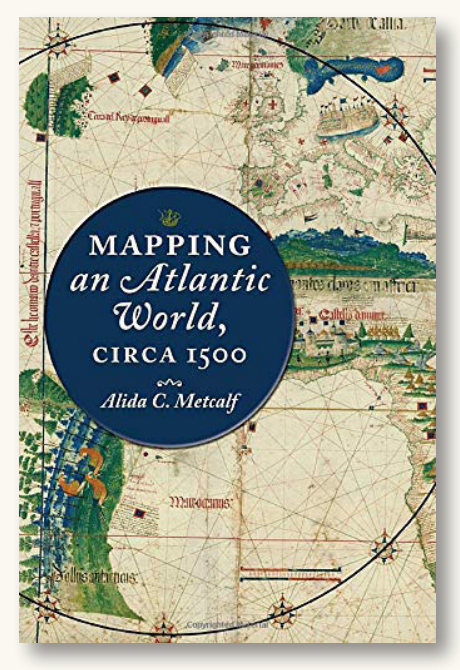

\title{
MAPPING AN ATLANTIC WORLD, CIRCA 1500
}

\author{
By Alida C. Metcalf
}

Johns Hopkins University Press, 2020

224 pages, $36 \mathrm{b \& w}$ and 12 color illus.

Hardcover: \$54.95, ISBN 978-1-4214-3852-8

Review by: Jörn Seemann, Ball State University

When Christopher Columbus set foot on the shores of the Caribbean island of San Salvador on October 12,1492 , he not only sparked the exploration and exploitation of the Americas by the European powers, but also provoked changes in how the entire world was depicted on their maps. The addition of a fourth continent, a "New World," led them to reconceptualize the world map over the following centuries. Before Columbus's first voyage, the world known to Europeans was limited to Asia, Africa, and Europe, and the complete extent of Africa had only recently become known, when the Portuguese navigator Bartolomeu Dias rounded the Cape of Good Hope in 1488. The spaces west of Europe and east of Asia remained blank or literally off the map-effectively beyond the edge of the Earth. Martin Behaim's famous Erdapfel terrestrial globe, constructed a short time before Columbus returned, illustrates clearly the concept of a spherical world without the Americas. The globe shows only a few islands (Canary Islands, Cabo Verde, the Azores, Madeira, and the imaginary islands of Saint Brendan and Antilia) scattered in the dark blue Atlantic Ocean. Empty spaces are filled with lengthy comments, the coats of arms of the Spanish and Portuguese crowns, several sailing vessels, and depictions of harmless-looking sea creatures. The first land encountered to the west of Europe is Cipangu, the present-day Japan, and even that is erroneously located in the latitude of the Tropic of Cancer (Ravenstein 1908). An animated version of the Erdapfel, based on Ravenstein's facsimile edition, can be found at the David Rumsey Map Collection.
This sets the scene for Mapping an Atlantic World, Circa 1500 by Alida Metcalf. As a "social and cultural historian [stepping] into the world of historical maps" (xxii), she investigates the first years of map production in Europe after Columbus's first voyage as a specific cartographic moment in time. She aims to understand not only how the first post1492 maps depicted the Atlantic and the Americas, but also how these maps conveyed knowledge about the ocean and became "powerful and persuasive arguments about the possibility of an interconnected Atlantic World" (1). For Metcalf, the persuasive discourse of cartography was a decisive moving force that drove merchants, soldiers, navigators and adventurers into "exploring, developing, and risking lives and fortunes in the distant lands of the western Atlantic" (2). The ocean was suddenly transformed, cartographically, from an open, infinite sea without boundaries into a complexly bounded, intercontinental, Atlantic World. Knowledge of the existence of a fourth continent in the West-albeit initially mistaken for eastern Asiacontinually changed the look and design of world maps during the sixteenth century as more and more information about the New World was brought in by navigators, sailors, and other informants. The focus of this book is on two handfuls of maps drawn or printed between 1500 and 1507 that document and illustrate the cartographic emergence of a wholly new transatlantic realm. Reading the scarce and unique maps from that time, and delving into the stories of their making, reveals the gestation of a new worldview that, in Meltcalf's words, depicted an Atlantic World rather than the Atlantic World. 
Each of the six chapters of the book chronologically and thematically approaches specific aspects of the cartography of the Atlantic world circa 1500. Chapter 1 presents a brief history of the mapping of the Atlantic Ocean from ancient Greece to 1492. Metcalf points out that throughout the period, the Atlantic remained a peripheral feature on maps. A prominent example is the medieval T-O mappa mundi based on Isidore of Seville's seventh-century encyclopedia. Although they understood the world to be spherical, European mapmakers showed the landmasses as floating islands framed by a circular, encompassing ocean. At the time, most world maps centered, variously, on the three known continents, on the Mediterranean Sea, or even on the Indian Ocean, but never on the Atlantic. This can be seen in such cartographic representations as the Atlas Catalan (1375) by the Majorcan mapmaker Abraham Cresques and the mappae mundi produced by Fra Mauro (1450), Henricus Martellus (ca. 1490), and Nicolò Germano (1466) — the latter map being very similar to the many fifteenth century versions of Ptolemy's cartography.

In Chapter 2, Metcalf takes a close look at the year 1500 as the "tipping point" (8) of the Atlantic Ocean reconceptualization. The years between Columbus's first voyage and the turn of the century resulted in anything but a feverish production of new world maps, and indeed, if any maps reflecting the Columbian discoveries were made before 1500, they have since disappeared. Even after that date, though, cartographic changes happened only slowly. The oldest known of these new charts is Juan de la Cosa's Portolan-style Carta Universal (1500), drawn on two pieces of calfskin. Hispaniola and Cuba are prominently positioned among a score of unnamed islands, and place names-written in red ink-extend southward along the South American coast, but there are almost no names on the shore to the north. The barrier of the continental landmass of the Americas (the west coast of which would only be seen by Europeans-in the person of Vasco Núñez de Balboa-in 1513) is shown as an anonymous expanse of dark green terra firma, divided by a portrait of Saint Christopher, the protector of mariners and travelers. Metcalf also guides the reader through several other early maps - for example, the Cantino Planisphere (1502, with images of trees and parrots positioned in what is today's Brazil), the King-Hamy Portolan (1502, showing the Americas as a simple thin line with a few named places), the so-called Contarini-Rosselli map (the first printed map showing the New World), and Martin Waldseemüller's
Universalis Cosmographia (1507), the first map with the label "America" on it.

Chapters 3 and 4 provide further insights into the contents of the maps, and the production processes and techniques involved in their making, as well as the lives and work of the fifteenth- and sixteenth-century mapmakers, cosmographers, and artists who made them. This was a time when manuscript map production was giving way to printing, and the change was a major factor in spreading ideas about the New World. Metcalf makes some interesting comparisons between the manuscript and printed mapsside-by-side comparisons of features (such as coastlines) and furniture (such as compass roses) - and observes that the printed products were notably more generalized and simplified. The new mass-produced maps were accessible to a broader population, but lost parts of their artistic character and their preciousness, and were easily discarded when out of date. The story of Waldseemüller's Universalis Cosmographia - a prominent example of the survival of a single copy of a printed map-is discussed at length in Chapter 4.

The last two chapters are dedicated to the pictorial elements on these early sixteenth-century maps and seeks to address how their visual language conveyed a specific idea of an Atlantic World through the use of colors and symbolic images. Metcalf compares the images of parrots and trees in different maps and discusses how and why these depictions evolved over time. In Chapter 6, she pays special attention to scenes of cannibalism, both as visual codes and as decorative fillers to transmit a stereotypical idea of the native population in the Americas.

In her conclusion, Metcalf speculates about reasons for the scarcity of early maps of the New World and further contends that it was the chartmakers and mapmakers, rather than the state, that "were [the] historical actors-often anonymous-who left a remarkable imprint on world history" (141). This was despite the fact that "there was not yet an accepted paradigm for how to place the Atlantic Ocean within the geography of the world, or even how to represent the world on a map" (141).

The book sheds light on different events and processes in the cartographic world "circa 1500." The author attempts to connect themes such as Atlantic history, the cultural history of mapmaking, and cartographic biographies to transmit an idea of the social, economic, and political 
contexts of the period. Admittedly, the idea for the book is nothing new. As Metcalf herself affirms, "almost all of the maps are available as high-resolution digital copies that can be consulted online through the websites of the libraries, archives, and museums that hold them" (xv). They are also well-known staples in many other books on the history of cartography - for example, Peter Barber's (2005) Map Book or Susan Schulten's (2018) A History of America in 100 Maps (reviewed in Cartographic Perspectives 92). Too, some of the cartographic stories presented in this book are "old hat" and have been discussed thoroughly, notably: pre-1492 cartography (Edson 2007; reviewed in Cartographic Perspectives 68) and the Waldseemüller map (Schwartz 2007; Lester 2010). Specifically, the early period mapping of the Atlantic World and the Americas has already been studied by Ravenstein (1908) in his biography of Martin Behaim, and by Fernández-Armesto (2007), who provides a detailed list of pre-1530 manuscript maps that show the relations between the Old and the New Worlds.

To be fair and frank, retelling cartographic history is not a mere repetition of facts and events. The most promising potential of Metcalf's book lies in its educational value. It could, for example, be used as an introductory read in undergraduate courses on map history or Atlantic history. Despite the existence of only a small number of historical cartographic sources, the author was able to draw a comprehensive picture of early sixteenth-century cartography and the mapping of the Atlantic World, though the limitation of the "circa 1500" time frame leaves the reader with a feeling of incompleteness. Akin to Chapter 1 ("The Atlantic on the Periphery"), which sets the stage of the book's theme by discussing maps before 1492, I can perfectly imagine a Chapter 7 that could engage briefly with map production after the first decade of the sixteenth century, when both the Atlantic and the Americas gradually gained their shapes.

The bibliography features a list of the maps mentioned in the book, along with internet links to the libraries that own them. I found this resource very useful, although the longevity of URLs is never guaranteed. The author has also created a web page (acm5.blogs.rice.edu) that contains all 36 figures and 12 color plates, along with brief comments on their contents and contexts, although this repository is not mentioned in the book itself. This very user-friendly website allows the reader to access the maps without wasting a lot of time on internet searches, and the online copies allow panning and zooming-a real advantage in exploring these large, complex, historical maps.

The book is an easy read, but I felt it did not expand quite enough on the discussion of some of its central ideas. When I read about the author's aim to frame these maps as powerful arguments for the creation of the concept of an interconnected Atlantic World, I was unsure in what direction the argument would lead, or how this hypothesis could be corroborated. Was it these maps that sparked a scramble for the Americas, or were the maps the result of a scramble? Were the individual mapmakers the true forces behind the map production, or were they simply entrepreneurs responding to an opportunity? Metcalf's stress on the contributions of individual mapmakers downplays the role of governments and their power of knowledge, but does not provide wholly convincing answers to the questions she raises. I was expecting more on the shaping of the Atlantic rim as a new geographic entity, with maybe an analysis similar to what Lewis and Wigen (1997) have called the "myth of continents." How, for example, did this particular area gain the status of a uniquely identifiable region? Some have written that, in the case of the Americas, this was not a result of simply adding the New World to the maps, but instead required a dramatic shift in European cosmography-a shift that did not happen overnight.

Once Europeans crossed the Atlantic, they gradually discovered that their threefold continental system did not form an adequate world model. Evidence of what appeared to be a single "new world" landmass somehow had to be taken into account. The transition from a threefold to a fourfold continental scheme did not occur immediately after Columbus, however. First, America had to be intellectually "invented" as a distinct parcel of land-one that could be viewed geographically, if not culturally, as equivalent to the other continents (Lewis and Wigen 1997, 25).

In conclusion, Mapping an Atlantic World, Circa 1500 is a light and entertaining read, especially for those who are not familiar with the cartographic history of the Renaissance. Reading through the pages, I became quite obsessed with the role of cartography in the invention and establishment of geographic concepts, and how both the maps and the concepts gained contents and substance over the years. The maps Alida Metcalf examines not only confirmed the existence and presence of a fourth continent, but also helped to consolidate the idea of a world centered 
on the Atlantic Ocean and based on Eurocentric and ethnocentric worldviews - a view that remains alive and well in the twenty-first century.

\section{REFERENCES}

Barber, Peter, ed. 2005. The Map Book. New York: Walker $\&$ Co.

Edson, Evelyn. 2007. The World Map, 1300-1492: The Persistence of Tradition and Transformation. Baltimore: Johns Hopkins University Press.

Fernández-Armesto, Felipe. 2007. Maps and Exploration in the Sixteenth and Early Seventeenth Centuries. In The History of Cartography, Volume 3: Cartography in the European Renaissance, edited by David Woodward, 738-770. Chicago: University of Chicago Press.
Lester, Toby. 2010. The Fourth Part of the World: An Astonishing Epic of Global Discovery, Imperial Ambition and the Birth of America. New York: Free Press.

Lewis, Martin, and Kären Wigen. 1997. The Myth of Continents: A Critique of Metageography. Berkeley, CA: University of California Press.

Ravenstein, Ernst Georg. 1908. Martin Behaim: His Life and His Globe. London: George Philip and Son.

Schulten, Susan. 2018. A History of America in 100 Maps. Chicago: University of Chicago Press.

Schwartz, Seymour. 2007. Putting "America" on the Map, the Story of the Most Important Graphic Document in the History of the United States. Amherst, NY: Prometheus Books. 